\title{
EVALUATION OF HEPATIC VASCULAR FLOW ALTERATIONS IN OBESE CHILDREN WITH AND WITHOUT NON-ALCOHOLIC FATTY LIVER DISEASE
}

\author{
Non-Alkolik Yağlı Karaciğer Hastalı̆̆ Olan ve Olmayan Obez Çocuklarda \\ Hepatik Vasküler Akım Değişikliklerinin Değerlendirilmesi
}

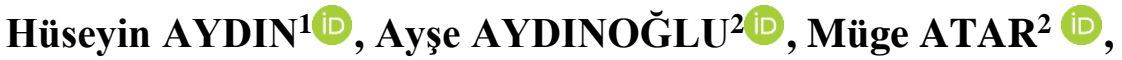 \\ Mustafa AKÇAM ${ }^{3}$, Özgür PİRGON ${ }^{2}$
}

\begin{abstract}
${ }^{I}$ Süleyman Demirel University, Faculty of Medicine, Department of Radiology, ISPARTA, TÜRKIYE
${ }^{2}$ Süleyman Demirel University, Faculty of Medicine, Deprt. of Ped. Endocrinology and Diabetes, ISPARTA, TÜRKIYE

${ }^{3}$ Süleyman Demirel University, Faculty of Medicine, Department of Pediatrics Gastroenterology, Hepatology and

Nutrition, ISPARTA, TÜRKIYE
\end{abstract}

\section{ABSTRACT}

Objective: To evaluate hepatic vascular flow alterations using Doppler ultrasound in obese children with and without nonalcoholic fatty liver disease.

Material and Methods: Ninety-one obese and 30 healthy lean (control) children were enrolled in this study. Obese children were divided into two groups: children with non-alcoholic fatty liver disease and children without non-alcoholic fatty liver disease; according to hepatic fatty changes on ultrasound, and blood serum alanine aminotransferase levels above $30 \mathrm{IU} / \mathrm{L}$. Portal vein diameter, portal blood flow volume and hepatic artery resistive index were calculated using Doppler ultrasound. Results: Portal vein diameter and portal blood flow volume values in children with non-alcoholic fatty liver disease were found close to the controls. However, the values of portal vein diameter and portal blood flow volume were lower in children without non-alcoholic fatty liver disease group than the other groups $(\mathrm{p}<0.001)$. Hepatic artery resistive index was higher in children without non-alcoholic fatty liver disease group than children with non-alcoholic fatty liver disease group $(0.64 \pm 0.1$ and $0.60 \pm 0.1$, respectively) ( $\mathrm{p}=0.03)$, whereas hepatic artery resistive index was found to be close in children with nonalcoholic fatty liver disease and controls. These findings were similar to the differences in hepatic vascular changes observed during the development of non-alcoholic fatty liver disease, which were described in physio-pathological studies.

Conclusion: Portal vein diameter, portal blood flow volume and hepatic artery resistive index values in obese children show significant differences according to the presence or absence of fatty liver. These differences are consistent with hepatic physio-pathological changes in non-alcoholic fatty liver disease. Therefore, hepatic vascular Doppler indices may be a new tool that can be used to monitor the development and progression of non-alcoholic fatty liver disease in obese children.

Keywords: Non-alcoholic fatty liver disease, portal vein, hepatic artery, Doppler ultrasound

\section{ÖZ}

Amaç: Non-alkolik yağlı karaciğer hastalığı olan ve olmayan obez çocuklarda hepatik vasküler akım değişikliklerini Doppler ultrason ile değerlendirmektir.

Gereç ve Yöntemler: Bu çalışmaya 91 obez ve 30 sağlıklı zayıf (kontrol) çocuk alındı. Obez çocuklar, ultrasondaki hepatik steatoz varlığı ve kan serumu alanin aminotransferaz düzeyinin 30 IU/L'nin üzerinde olması durumuna göre, non-alkolik yağlı karaciğer hastalığı olan ve non-alkolik yağlı karaciğer hastalığ olmayan şeklinde iki gruba ayrıldı. Portal ven çapı, portal ven akım hacmi ve hepatik arter rezistif indeksi Doppler ultrason kullanilarak hesaplandi.

Bulgular: Non-alkolik yağlı karaciğer hastalığında portal ven çapı ve portal ven akım hacmi değerleri kontrol grubuna yakın bulundu. Ancak non-alkolik yağlı karaciğer hastalığı olmayan grupta portal ven çapı ve portal ven akım hacmi değerleri, diğer gruplara göre daha düşüktü $(\mathrm{p}<0.001)$. Hepatik arter rezistif indeksi değerleri, non-alkolik yağlı karaciğer hastalığı olmayan grupta non-alkolik yağlı karaciğer hastalığı grubundan istatistiksel olarak anlamlı yüksek bulundu (sırasıyla $0.64 \pm 0.1$ ve $0.60 \pm 0.1)(\mathrm{p}=0.03)$. Buna karşın, non-alkolik yağlı karaciğer hastalığ 1 ve kontrol gruplarında hepatik arter rezistif indeksi değerleri birbirine yakındı. Bulgular, fizyopatolojik çalışmalarda tanımlanmış, non-alkolik yağlı karaciğer hastalığı gelişim sürecinde izlenen, hepatik vasküler değişimlerdeki farkl11ıklar ile benzerdi.

Sonuç: Obez çocuklarda portal ven çapı, portal ven akım hacmi ve hepatik arter rezistif indeksi değerleri karaciğer yağlanması olup olmamasına göre anlamlı farklılıklar göstermektedir. Bu farklılıklar non-alkolik yağlı karaciğer hastalığındaki hepatik fizyopatolojik değişimler ile uyumludur. Bu nedenle, hepatik vasküler Doppler indeksleri obez çocuklarda non-alkolik yağlı karaciğer hastalığı gelişimi ve ilerlemesinin takibinde kullanılabilecek yeni bir araç olabilir.

Anahtar Kelimeler: Non alkolik yă̆ll karaciğer hastalı̆̆, portal ven, hepatik arter, Doppler ultrasonografi

\section{Dr. Hüseyin AYDIN}

Süleyman Demirel University, Faculty of Medicine, Department of Radiology, ISPARTA, TÜRKIYE

Phone / Tel: +90 5055790290

Received / Geliş Tarihi: 02.09.2021

E-mail / E-posta: huseyinrad@gmail.com

Accepted / Kabul Tarihi: 04.10.2021 


\section{INTRODUCTION}

Non-alcoholic fatty liver disease (NAFLD) is the accumulation of fat in the liver and can progress to simple liver steatosis, cirrhosis or even to hepatocellular carcinoma (1). There is an increase in the prevalence of NAFLD, especially in the adolescent age group (2). Besides, it has been reported that pediatric NAFLD frequently transforms into cirrhosis in adulthood. Therefore, early diagnosis and close monitoring of NAFLD is essential (3).

In NAFLD, intrahepatic blood pressure changes occur throughout the disease course. The physio-pathological bases on which these changes occur during this process are also different (4). It has been shown in rats that portal hypertension developed in the early stages of NAFLD, in which inflammation and fibrosis did not develop yet (5). In excessive and frequent feeding, the blood volume coming to the liver via the portal venous flow increases (hepatic congestion). To balance the total hepatic blood volume, the oxygen-rich hepatic artery flow volume is reduced by splanchnic vasoconstriction defined as the "hepatic arterial buffer response" (6). Hepatic portal venous congestion and vasoconstrictive mechanisms are primarily responsible for this intrahepatic pressure increase in early NAFLD, whereas parenchymal stiffening due to inflammation and fibrosis is responsible for increased intrahepatic pressure in progressed NAFLD (5-8). These effects of NAFLD on hepatic vascular structures can be evaluated by Doppler ultrasound (US).

It is important to know the mechanism of vascular changes in these stages when performing NAFLD evaluation with Doppler US. Although the relationship between NAFLD and hepatic and portal vein hemodynamics has been reported in adult studies, there isn't sufficient knowledge about hepatic vascular flow in children with NAFLD (9-13). This study aimed to determine the changes in the hepatic vascular system in obese children with/without NAFLD using doppler US.

\section{MATERIALS AND METHODS}

\section{Study Population}

The study plan was approved by the Ethics Committee of our hospital. In this retrospective case-control study, a total of 121 children (91 obese and 30 healthy lean children as control) who applied to our hospital between December 2018 and May 2019 were included. Since it was a retrospective study, it was not necessary to obtain patient consent. However, permission was obtained from the administration of our hospital for the use of patient information recorded in the PACS system. Clinical-laboratory and ultrasound data of the patients were obtained from the PACS system and ultrasound memory. For Turkish adolescents, patients with a body mass index (BMI) >95 percentile according to the reference curves are defined as obese. Obese subjects were divided into two groups as NAFLD and non-NAFLD. NAFLD assessment is more effective in obese children using US together with alanine aminotransferase (ALT) $(14,15)$. NAFLD was defined according to the ultrasound findings (hepatorenal echo contrast, liver brightness, deep attenuation, and vascular wall turbidity together with) and elevated serum ALT levels ( $\geq 30$ IU/L) (16-18). Those with no signs of steatosis on ultrasound and an ALT value below 30 IU/L constituted the non-NAFLD group. Inclusion criteria for the NAFLD group were elevated liver enzymes for $>6$ months and ultrasound findings of fatty liver. Laboratory investigations were performed to exclude other liver diseases that cause increased echogenicity in the liver, including viral hepatitis, autoimmune hepatitis, hemochromatosis, and Wilson's disease. The control participants chosen from non-obese, healthy children who attended the hospital for minor illnesses such as a common cold, nonspecific abdominal pain, or similar mild afflictions were enrolled in the study. 


\section{Gray Scale and Doppler Ultrasound Parameters}

Ultrasound examination was performed by a single radiologist (HA, with 23 years of ultrasonography experience) who was blinded to all laboratory results of the participants, using a Philips EPIQ-5 machine (Philips Medical System), 1-5 MHz curved array transducer. US examination was performed in the supine position with a breath hold after slight inspiration with a subcostal and oblique intercostal approach (for portal vein flow measurements) after at least 6 hours of fasting and at least 15 minutes of rest. In the B-mode examination, portal vein diameter (PVD) was measured at the hepatic artery crossing (19). Standard Doppler parameters (maximum gain without background noise, lowest pulse repetition frequency values without aliasing artifact, lowest wall filter that would not lead to an artifact, $2 \mathrm{~mm}$ sample volume and $30^{\circ}-60^{\circ}$ Doppler angle) were used and spectral analysis was recorded for at least 5 seconds (20). Portal vein (PV) Doppler US measurements were performed in the main PV before bifurcation at the hepatic hilum at intercostal approach (Figure 1A, 1B), and the hepatic artery (HA) was measured at the level of the anterior course of PV at the hepatic portal at subcostal approach (Figure 1C). Measurements were repeated 3 times and mean values were taken into consideration. Because the diameter of the hepatic artery was thin in the pediatric group and velocity measurements were highly affected by angular differences, hepatic artery velocity and flow volume were not calculated. Instead, hepatic artery resistivity index (HARI) measurement independent of angular variables was performed. HARI was obtained automatically by the software of the ultrasound device after manual measurement of peak systolic velocity (PSV) and end-diastolic velocity (EDV) (20). Portal vein peak systolic velocity (PV-PSV), PV end-diastolic velocity (PV-EDV), PV pulsatility (PVP), PV pulsatility index (PVI), PV maximum blood flow volume (PBFV) and modified hepatic vascular index (MHVI) values were calculated. These indices were calculated according to the following equations:

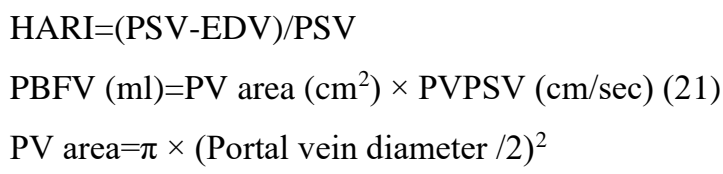

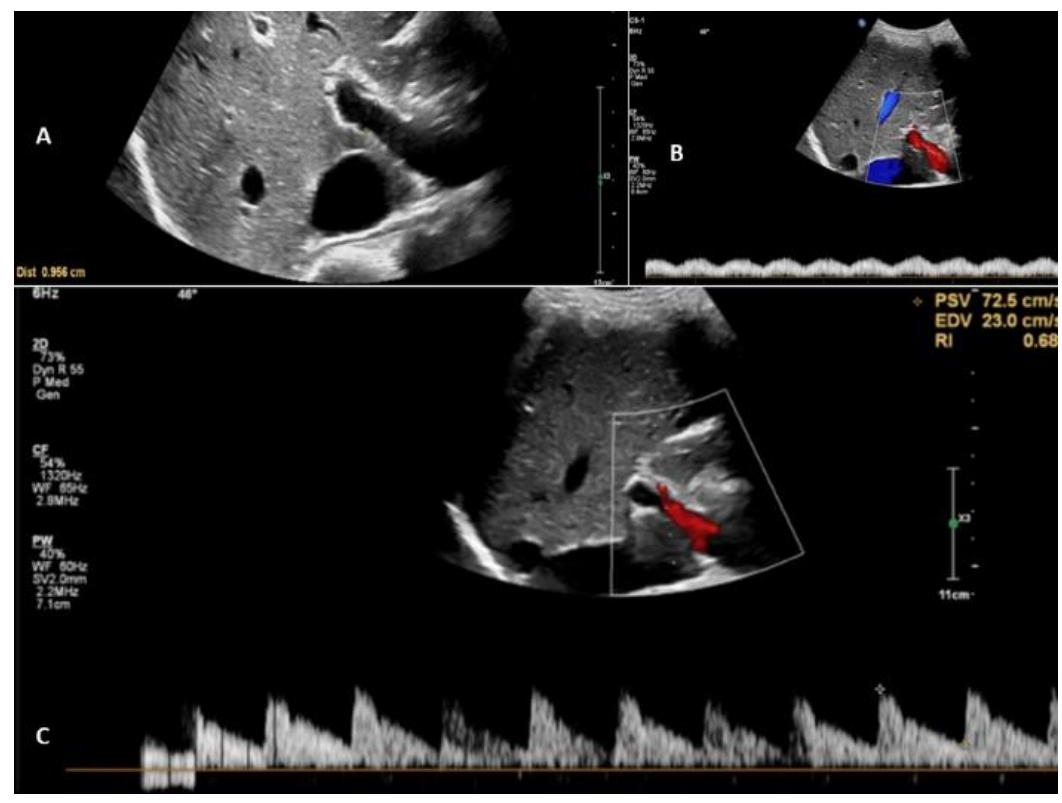

Figure 1: A) Portal vein diameter measurement B) Portal vein velocity C) Hepatic artery resistive index measurement 


\section{Statistical Analyses}

The descriptive statistics were presented as mean \pm standard deviation (SD) and as frequency (percentage) for the gender variable. One-way ANOVA was used for comparison between the groups with Tukey HSD post-hoc test since the continuous variables were distributed normally. Pearson's correlation analysis was performed to see the relationships between biochemical and Doppler US measurements. Two-sided $\mathrm{p}<0.05$ was considered as statistically significant result for 5\% type-I error. The statistical analyses of the study were performed using SPSS 20.0 software (IBM Inc., Chicago, Illinois, USA).

\section{RESULTS}

A total of 121 cases, 91 obese and 30 controls, were evaluated. Characteristics of the study groups are shown in Table 1. NAFLD group was composed of 20 boys and 5 girls (mean age 13.7 \pm 2.6 years, and mean BMI: $31.2 \pm 5.1$ ), and non-NAFLD group included 24 boys and 42 girls (mean age 13.9 \pm 2.1 years, and BMI: $31.1 \pm 4.2)$. The control group was composed of 14 boys, and 16 girls (mean age 14.9 \pm 1.4 years and BMI:
21.3 \pm 3.1$)$. Age and gender distributions were similar in all three groups. None of the measurements were found to be significantly different based on gender. Fasting insulin levels were higher in the non-NAFLD and NAFLD obese groups than in the normal subjects $(\mathrm{p}<0.001)$. HOMA-IR was found to be increased in the obese groups and was higher in the non-NAFLD group $(\mathrm{p}<0.001)$.

On gray scale US examination, $68 \%(17 / 25)$ of the NAFLD patients had mild steatosis, 20\% (5/25) moderate and $12 \%(3 / 25)$ severe steatosis. Gray scale and Doppler US examination data in all groups are shown in Table 2.

On Doppler US examination, PVD measurements were found significantly lower in the non-NAFLD group than the NAFLD group $(\mathrm{p}=0.003)$. PBFV values were found to be decreased in non-NAFLD group compared to the NAFLD and control groups $(913 \pm 414,1165 \pm 501$ and $1245 \pm 1084 \mathrm{ml} / \mathrm{min}$, respectively). HARI values were detected higher in the non-NAFLD group than in the other groups $(\mathrm{p}=0.008)$. However, no significant difference was found among NAFLD and controls (Figure 2). PV-PSV, PV-EDV, PVPI, PVP and MHVI measurement values were not significantly different between the groups.
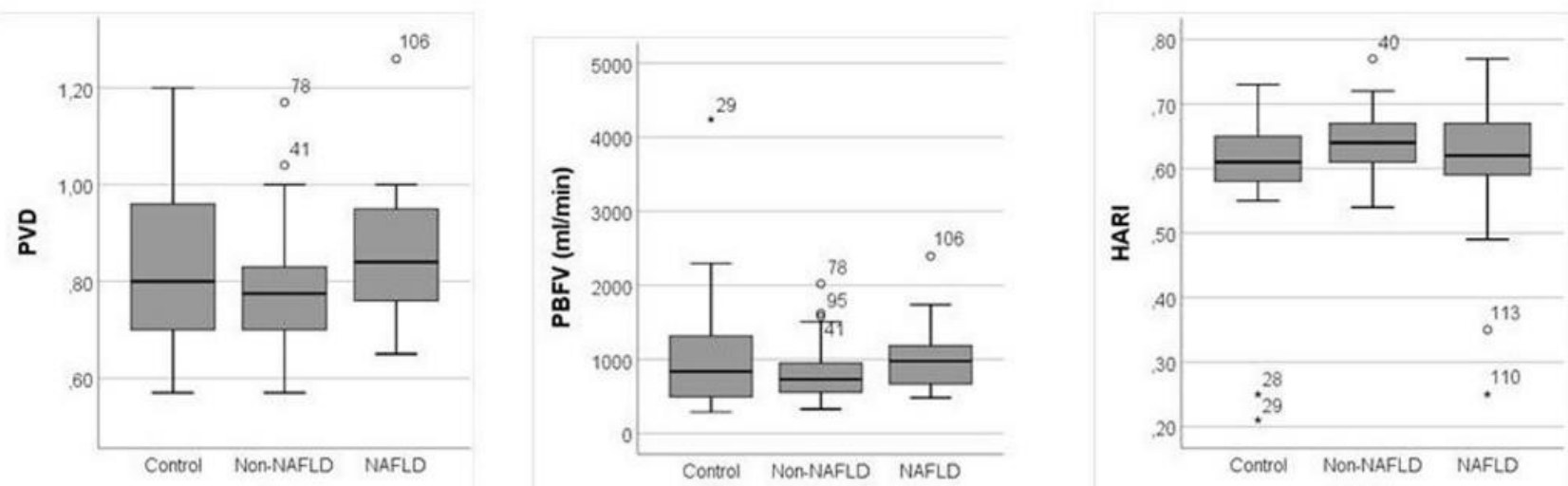

Figure 2. Assessment of hepatic artery and portal vein hemodynamics in obese children with fatty liver PVD: portal vein diameter; PBFV: portal blood flow volüme; HARI: Hepatic artery resistive index 
The relationship between PVD, HARI, PBFV and ALT values were significantly different in obese groups when tested by Pearson's correlation test (Table 3). Negative correlation was found between HARI and ALT levels in NAFLD group $(r=-0.493 ; p=0.012)$.
There were positive correlations between BMI and PBFV ( $\mathrm{r}=0.469, \mathrm{p}<0.001)$, and BMI and PVD measurements $(r=0.659, \mathrm{p}<0.001)$ in NAFLD patients. HARI values were not correlated with BMI in both obese groups.

Table 1: Characteristics of the study groups

\begin{tabular}{lccc}
\hline & & \multicolumn{2}{c}{ Obese Patients } \\
\hline n (males/females) & Controls & non-NAFLD & NAFLD \\
\cline { 2 - 4 } Age (years) & $30(14 / 16)$ & $66(24 / 42)$ & $25(20 / 5)$ \\
Body mass index $\left(\mathrm{kg} / \mathrm{m}^{2}\right)$ & $14.9 \pm 1.4$ & $13.9 \pm 2.1$ & $13.7 \pm 2.6$ \\
Alanine amino transferase (IU/L) & $21.3 \pm 3.1$ & $31.1 \pm 4.2^{\alpha}$ & $31.2 \pm 5.1^{\phi}$ \\
Fasting insulin (IU/mL) & $14.3 \pm 5$ & $18.5 \pm 8.1^{\alpha}$ & $72.8^{\alpha} \pm 42.4^{\phi}$ \\
HOMA-IR & $18.4 \pm 10.7$ & $27.2 \pm 17.6^{\alpha}$ & $33.6 \pm 15.9^{\phi, r}$ \\
\hline
\end{tabular}

NAFLD: Non-alcoholic fatty liver disease; HOMA-IR: Homeostatic Model Assessment for Insulin Resistance $\alpha: p<0.05$ level at controls and non-NAFLD; $\phi: p<0.05$ level at controls and NAFLD; $\gamma: p<0.05$ level at non-NAFLD and NAFLD

Table 2: Gray scale and Doppler ultrasound measurements of the study groups

\begin{tabular}{lccc}
\hline & & \multicolumn{2}{c}{ Obese Patients } \\
\cline { 2 - 4 } PVD $(\mathrm{cm})$ & Controls & non-NAFLD & NAFLD \\
HARI & $0.8 \pm 0.1$ & $0.7 \pm 0.1^{\gamma}$ & $0.8 \pm 0.1$ \\
PV-PSV $(\mathrm{cm} / \mathrm{s})$ & $0.60 \pm 0.1$ & $0.64 \pm 0.1^{\alpha}$ & $0.61 \pm 0.1$ \\
PV-EDV (cm/s) & $36.2 \pm 21.2$ & $31.8 \pm 9.5$ & $33.1 \pm 9.5$ \\
PVPI & $24.4 \pm 8.8$ & $23.3 \pm 6$ & $24.4 \pm 7.3$ \\
PVP & $0.20 \pm 0.1$ & $0.26 \pm 0.1$ & $0.26 \pm 0.1$ \\
MHVI & $0.70 \pm 0.1$ & $0.74 \pm 0.1$ & $0.74 \pm 0.1$ \\
PBFV (ml/min) & $76.6 \pm 11.7$ & $50 \pm 15.4$ & $57.9 \pm 23.4$ \\
\end{tabular}

NAFLD: Non-alcoholic fatty liver disease; HARI: Hepatic artery resistive index; PVD: portal vein diameter; PV-PSV: Peak systolic portal vein velocity; PV-EDV: End-diasrtolic portal vein velocity; PVPI: portal vein pulsatility index; PVP: portal vein pulsatility; MHVI: modified hepatic vascular index; PBFV: portal vein blood flow $\alpha: \mathrm{p}<0.05$ level at controls and non-NAFLD; $\phi: \mathrm{p}<0.05$ level at controls and NAFLD; $\gamma: \mathrm{p}<0.05$ level at non-NAFLD and NAFLD

Table 3: The Pearson's correlation coefficients between Hepatic artery resistive index (HARI), portal vein blood flow $(\mathrm{PBFV})$, portal vein diameter (PVD) and metabolic parameters in obese children groups

\begin{tabular}{llcccc}
\hline & \multicolumn{3}{c}{ Obese Patients } \\
& & \multicolumn{2}{c}{ non-NAFLD } & \multicolumn{1}{c}{ NAFLD } \\
\cline { 3 - 6 } HARI & ALT & $\mathrm{r}$ & $\mathrm{p}$ & $\mathrm{r}$ & $\mathrm{p}$ \\
PBFV & BMI & -0.173 & 0.165 & -0.493 & 0.012 \\
PVD & BMI & 0.047 & 0.709 & 0.469 & 0.018 \\
\hline
\end{tabular}

NAFLD: Non-alcoholic fatty liver disease; HARI: Hepatic artery resistive index; PBFV: Portal vein blood flow; PVD: Portal vein diameter; ALT: Alanine amino transferase; BMI: Body mass index. 


\section{DISCUSSION}

The most striking finding of this study was that PVD, PBFV and HARI values were similar in NAFLD and control groups. However, PVD and PBFV values decreased, and HARI values increased in the nonNAFLD group. In this study, Doppler US findings in NAFLD groups showed parallelism with vascular physio-pathological changes reflecting the disease stage during the development of NAFLD. NonNAFLD Doppler indices reflect the early period in which vasoconstrictive reflex is dominant, and NAFLD group Doppler indices reflect the advanced stage of NAFLD in which vasodilator reflex is dominant. The fact that these pathophysiological changes can be demonstrated by Doppler US suggests that Doppler US may be of great benefit in evaluating the development and progression of NAFLD in pediatric obese patients. However, in order to confirm this finding, multicentered studies are needed to determine the cutoff values of Doppler indices and to test the interobserver and intra-observer reliability.

Many studies have reported different results regarding changes in the portal vein and hepatic artery indices in NAFLD (9-12,24). However, the reason for this difference has not been fully elucidated. According to the reasons for the discordant hepatic vascular index results reported in these studies, it can be said that the study groups were not homogeneous in terms of age and NAFLD disease duration, and the use of nonstandard measurement techniques (9-12). The present study suggests that an important reason for the difference in hepatic vascular index results reported in previous studies may be because of the disease duration. In this study, Doppler indices of the early stages of NAFLD, in which chronic liver disease has not yet developed, were evaluated, with the study groups consisting of children with NAFLD with a shorter disease duration. Because obese patients are at higher risk for developing NAFLD, as mentioned above, the data in the non-NAFLD group and the data in the NAFLD group showed parallelism with the pathophysiological vascular changes defined in the development of NAFLD (15). Hizli et al., found that HARI was positively correlated with the degree of fat and BMI in pediatric NAFLD patients, thereby it shows the lack of hepatic artery perfusion (11). The mean ALT value in the group they defined as overweight in their study was $19.58 \pm 6 \mathrm{IU} / \mathrm{L}$. The Doppler findings and ALT values in their study correspond to non-NAFLD values in the present study. Gonçalves et al., stated that in their study $89.79 \%$ of patients had non-alcoholic steatohepatitis histologically and, HARI did not show any significant difference between the NAFLD group and the control group (25). Therefore, they commented that HARI was not effective in distinguishing NAFLD from the control group. Similarly, in our study, the HARI values of the NAFLD group were not different from the control group. The reason for this was thought to be compensatory vasodilation in the NAFLD period. Because in this period, PVD and PBFV values were higher than non-NAFLD group. PVD, PBFV, ALT values, and clinical status should be considered when interpreting HARI. Therefore, unlike Gonçalves et al., HARI can be considered as a parameter that distinguishes NAFLD from non-NAFLD. In addition, HARI showed a negative correlation with ALT in the NAFLD group in this study consistent with the literature $(3,26,27)$. In the later stages of NAFLD, there is an intense inflammation and fibrosis, and HARI values tend to increase with increased resistance in front of the hepatic artery, which is no longer compensated by the "Hepatic Artery Buffer Response". HARI values, generally correlate positively with the degree of fibrosis, have been reported in patients with advanced NAFLD and cirrhosis $(22,23,28,29)$. In this study, Doppler indices of advanced stage NAFLD and cirrhosis could not be evaluated, due to the low number of advanced stages of NAFLD and the absence of patients with cirrhosis. In the literature, different results 
have been reported for portal vein flow rates and vascular pulsatility indices, probably due to differences in operating as previously noted $(9,10)$. In this study, no significant changes were found in portal vein velocities and portal vein pulsatility indices in the groups. However, PV diameter and PBFV values were found to be low in non-NAFLD in accordance with physio-pathological reflex mechanisms, but higher in NAFLD group. As mentioned above, HARI, together with PVD, PBFV and ALT levels in pediatric obese patients, can help to accurately assess the development and progress of NAFLD. However, there is a need for studies involving larger numbers of patients in which cut-off values will be established.

This study demonstrates that there are positive correlations between BMI and PVD and PBFV in the NAFLD group. This is consistent with increased insulin-induced nutrition and Doppler findings in the NAFLD. Although the fasting insulin levels and Homeostatic Model Assessment for Insulin Resistance (HOMA-IR) were higher in the obese groups, they were more prominent in NAFLD. Soresi et al. also found a negative correlation between HOMA-IR and HARI and a positive correlation between PVD in adult patients with metabolic syndrome (10). These findings are consistent with the NAFLD findings in the current pediatric study. In addition, in the NAFLD group, HARI showed a negative correlation with ALT.

There were some limitations in this study:

1. The most important limitation of this study was that the degree of hepatosteatosis was not known pathologically because biopsy was not performed. It is not ethical to perform biopsy for the diagnosis of NAFLD, except for special cases, since it has undesirable risks. Therefore, we made the diagnosis of NAFLD by non-invasive methods.

2. It is likely that some obese children classified as "non-NAFLD" actually had liver steatosis. Because the sensitivity of the B-mode US technique is limited as explained in the literature $(14,16,30)$.

3. Hepatorenal echo index, which is a kind of quantitative assessment method of steatosis with US, could not be performed due to technical limitations. For the same reasons, another quantitative method, elastography, could not be studied. Moreover, evaluation of early stage NAFLD by elastography was not found sufficient in the literature (28). Hepatosteatosis can also be evaluated quantitatively with magnetic resonance imaging (MRI). By performing studies comparing Doppler findings with MRI quantitative values, the validity of our findings can be tested.

4. Performing the ultrasound examination by a single person was an important limitation of the study.

5. The number of participants in the NAFLD group was relatively small. Moreover, there were no patients with cirrhosis due to NAFLD in the study group. Therefore, changes in vascular structures in the advanced clinical stages of NAFLD were interpreted by synthesis from previous studies.

6. Since it is a cross-sectional study, the relation of the results with NAFLD is not clear. There is a need for prospective Doppler studies should be conducted before and after the treatment to compare quantitative methods.

In conclusion, significant differences in hepatic vascular indices were found between NAFLD and nonNAFLD in obese children with Doppler US examination. These differences may reflect the vascular physio-pathological changes in the development and progression of fatty liver in obese children. Therefore, Doppler indices may be a new tool that can be used in the development and clinical follow-up of NAFLD in obese children. However, in order to evaluate the accuracy of this finding, prospective Doppler US studies are needed to be conducted comparatively with quantitative methods. 
Conflict of Interest: The authors declare that they have no conflict of interest.

Support and Acknowledgment: This research received no specific grant from any funding agency in the public, commercial, or not-for-profit sectors.

Researchers' Contribution Rate Statement: ConceptDesign: HA, ÖP; Data Collection and Processing: AA, HA, MA; Analysis and Interpretation: HA; Literature Search: HA; Writing Manuscript: HA; Critical Review: ÖP, MA; Validation: HA, AA, MA, MA, ÖP.

Ethics Committe Aproval: Süleyman Demirel University Faculty of Medicine Clinical Research Ethics Committee, date: 18.08.2021, issue number: 65 .

Informed Consent: Informed consent was obtained from all individual participants included in the study.

\section{REFERENCES}

1. Friedman SL, Neuschwander-Tetri BA, Rinella M, Sanyal AJ. Mechanisms of NAFLD development and therapeutic strategies. Nat Med. 2018;24(7):908-22.

2. Akcam M, Boyaci A, Pirgon O, Koroglu M, Dundar BN. Importance of the liver ultrasound scores in pubertal obese children with nonalcoholic fatty liver disease. Clin Imaging. 2013;37(3):504-8.

3. Mosca A, Panera N, Crudele A, Alisi A. Noninvasive diagnostic tools for pediatric NAFLD: where are we now? Expert Rev Gastroenterol Hepatol. 2020:14(11):1035-46.

4. Buzzetti E, Pinzani M, Tsochatzis EA. The multiple-hit pathogenesis of non-alcoholic fatty liver disease (NAFLD). Metabolism. 2016;65(8):1038-48.

5. Francque S, Laleman W, Verbeke L, Van Steenkiste C, Casteleyn C, Kwanten W et al. Increased intrahepatic resistance in severe steatosis: endothelial dysfunction, vasoconstrictor overproduction and altered microvascular architecture. Lab Investig. 2012;92(10):1428-39.

6. Francque S, Verrijken A, Mertens I, Hubens G, Van Marck E, Pelckmans $P$ et al. Noncirrhotic human nonalcoholic fatty liver disease induces portal hypertension in relation to the histological degree of steatosis. Eur J Gastroenterol Hepatol. 2010;22(12):1449-57.

7. van der Graaff D, Kwanten WJ, Francque SM. The potential role of vascular alterations and subsequent impaired liver blood flow and hepatic hypoxia in the pathophysiology of non-alcoholic steatohepatitis. Med Hypotheses. 2019;122:188-97.

8. Lautt WW. Regulatory processes interacting to maintain hepatic blood flow constancy: vascular compliance, hepatic arterial buffer response, hepatorenal reflex, liver regeneration, escape from vasoconstriction. Hepatol Res. 2007;37(11):891903.

9. Balasubramanian P, Boopathy V, Govindasamy E, Venkatesh BP. Assessment of portal venous and hepatic artery haemodynamic variation in nonalcoholic fatty liver disease (NAFLD) patients. J Clin Diagnostic Res. 2016;10(8):TC07.

10. Soresi M, Giannitrapani L, Noto D, Terranova A, Campagna ME, Cefalù $\mathrm{AB}$ et al. Effects of steatosis on hepatic hemodynamics in patients with metabolic syndrome. Ultrasound Med Biol. 2015;41(6):1545-52.

11. Hizli S, Koçyigit A, Arslan N, Tuncel SA, Demircioglu F, Cakmakçi $H$ et al. Hepatic artery resistance in children with obesity and fatty liver. Indian J Pediatr. 2010;77(4):407-11.

12. Mohammadi A, Ghasemi-Rad M, Zahedi H, Toldi G, Alinia T. Effect of severity of steatosis as assessed ultrasonographically on hepatic vascular indices in non-alcoholic fatty liver disease. Med Ultrason. 2011;13(3):200-6. 
13. Tarzamni MK, Khoshbaten M, Sadrarhami S, Daneshpajouhnejad P, Jalili J, Gholamian M et al. Hepatic artery and portal vein doppler indexes in non-alcoholic fatty liver disease before and after treatment to prevent unnecessary health care costs. Int J Prev Med. 2014;5(4):472-7.

14. Ezaizi Y, Kabbany MN, Selvakumar PKC, Sarmini MT, Singh A, Lopez R et al. Comparison between non-alcoholic fatty liver disease screening guidelines in children and adolescents. JHEP Reports. 2019;1(4):259-64.

15. Suri A, Song E, van Nispen J, Voigt M, Armstrong A, Murali V et al. Advances in the epidemiology, diagnosis, and management of pediatric fatty liver disease. Clin Ther. 2021;43(3):438-54.

16. Tominaga K, Kurata JH, Chen YK, Fujimoto E, Miyagawa S, Abe I et al. Prevalence of fatty liver in Japanese children and relationship to obesity. Dig Dis Sci. 1995;40(9):2002-9.

17. Schwimmer JB, Dunn W, Norman GJ, Pardee PE, Middleton MS, Kerkar N et al. SAFETY study: alanine aminotransferase cutoff values are set too high for reliable detection of pediatric chronic liver disease. Gastroenterology. 2010;138(4):135764,1364.e1-2.

18. Fraser A, Longnecker MP, Lawlor DA. Prevalence of elevated alanine aminotransferase among US adolescents and associated factors: NHANES 1999-2004. Gastroenterology. 2007;133(6):181420.

19. Ferraioli G, Wong VW-S, Castera L, Berzigotti A, Sporea I, Dietrich CF et al. Liver ultrasound elastography: an update to the world federation for ultrasound in medicine and biology guidelines and recommendations. Ultrasound Med Biol. 2018;44(12):2419-40.

20. Choi SH, Kwon JH, Kim KW, Jang HY, Kim JH, Kwon $\mathrm{H}$ et al. Measurement of liver volumes by portal vein flow by Doppler ultrasound in living donor liver transplantation. Clin Transplant. 2017;31(9):e13050.

21. Kim SH, Choi MS, Kim MJ, Kim YH, Cho SH. Role of semi-quantitative dynamic contrastenhanced MR imaging in characterization and grading of prostate cancer. Eur $\mathbf{J}$ Radiol. 2017;94:154-9.

22. Zhang L, Duan YY, Li JM, Yin JK. Hemodynamic features of Doppler ultrasonography in patients with portal hypertension: intraoperative direct measurement of portal pressure in the portal venous system. J Ultrasound Med. 2007;26(12):1689-96.

23. Rocha HLOG, Diniz ALD, Borges VF de A e, Salomão FC. Assessment of portal venous index as a non-invasive method for diagnosing liver fibrosis in patients with chronic hepatitis C. Arq Gastroenterol. 2012;49(1):14-8.

24. Belotta AF, Teixeira CR, Padovani CR, Rahal SC, Mayer MN, Mamprim MJ. Sonographic evaluation of liver hemodynamic indices in overweight and obese dogs. J Vet Intern Med. 2018;32(1):181-7.

25. ML GDRM, Ferreira De Almeida EB V, Machado De Alcântara T, Borges De Araújo L, De Fátima Pinheiro C. Liver hemodynamic patterns in nonalcoholic steatosis: Doppler ultrasonography and histological evaluation. Minerva Gastroenterol Dietol. 2016;62(1):19-29.

26. Singh SP, Barik RK. Noninvasive biomarkers in nonalcoholic fatty liver disease: Are we there yet? J Clin Exp Hepatol. 2020;10(1):88-98.

27. Draijer LG, Feddouli S, Bohte AE, Rijcken THP, Benninga MA, Stoker J, et al. Comparison of diagnostic accuracy of screening tests ALT and ultrasound for pediatric non-alcoholic fatty liver disease. Eur J Pediatr. 2019;178(6):863-70.

28. Tana C, Tana M, Rossi S, Silingardi M, Schiavone C. Hepatic artery resistive index (HARI) and nonalcoholic fatty liver disease (NAFLD) fibrosis score in NAFLD patients: cut-off suggestive of non- 
alcoholic steatohepatitis (NASH) evolution. J Ultrasound. 2016;9(3):183-9.

29. Lim YS, Kim WR. The global impact of hepatic fibrosis and end-stage liver disease. Clin Liver Dis. 2008;12(4):733-46.

30. Vos MB, Abrams SH, Barlow SE, Caprio S, Daniels SR, Kohli R et al. NASPGHAN clinical practice guideline for the diagnosis and treatment of nonalcoholic fatty liver disease in children: recommendations from the Expert Committee on NAFLD (ECON) and the North American Society of Pediatric Gastroenterology, Hepatology and Nutrition (NASPGHAN). J Pediatr Gastroenterol Nutr. 2017;64(2):319-34. 